\title{
Origin of the Amazonian Rainforest
}

\author{
Nils-Axel Mörner \\ Paleogeophysics \& Geodynamics, Stockholm, Sweden \\ Email: morner@pog.nu
}

Received 7 March 2016; accepted 16 April 2016; published 19 April 2016

Copyright (C) 2016 by author and Scientific Research Publishing Inc.

This work is licensed under the Creative Commons Attribution International License (CC BY). http://creativecommons.org/licenses/by/4.0/

\begin{abstract}
In the last 30 ma, the passive continental margin of South America and the Amazonian basin experienced three periods of major sea level inundation; viz. at around $20 \mathrm{ma}$, at around $10 \mathrm{ma}$ and at around $3 \mathrm{ma}$. The establishment of the immense Amazonian rainforest ecosystem covering some 6 million square $\mathrm{km}$ can neither have occurred during the periods of high sea level nor at the intermediate periods of arid or semi-arid climatic conditions. Therefore, the origin of the Amazonian rainforest of present-day dimensions must be set at the Late Miocene. The establishment of the Amazonian rainforest implied the withdrawal of enormous quantities of water from the global hydrological cycle. The drastic increase in evaporation leading to the Messinian salinity crisis in the Mediterranean occurred at the same time as the Amazonian rainforest (sensu hodierno) establishment suggesting a causal linkage.
\end{abstract}

\section{Keywords}

Amazonian Rainforest, Sea Level Changes, Andean Uplift, Messinian Crisis, Late Miocene

\section{Introduction}

The Amazonian rainforest covers an area of more than 6 million $\mathrm{km}^{2}$ centered around the huge Rio Amazonas fluvial system from the mountain slopes in the west to the delta area in the east (approximately Long. $75^{\circ} \mathrm{W}$ $45^{\circ} \mathrm{W}$ and Lat. $5^{\circ} \mathrm{N}-15^{\circ} \mathrm{S}$ ). The rainforest ecosystem is truly unique. The biodiversity is higher than in any other ecosystem on Earth. It includes some 80,000 vascular plant species and 30 million animal species, including 2000 different fishes.

In order to understand the dynamics, evolution and speciation of this unique ecosystem, it is of vital importance to know both the precise time of formation and the circumstances of the formation of the Amazonian rainforest system. The rainforest does not have a very high age, however. With a probable early onset along the western margins [1], the immense Amazonian rainforest ecosystem of present-day dimensions primarily seems to have come into being in the Late Miocene ([2], their Figure 3(F)). In the Late Cretaceous, large areas of South America were covered by the sea. The Cordillera—-the Andes—did not exist. The Amazonas was not yet "born"; 
neither the fluvial system nor the rainforest ecosystem. With the Tertiary uplift of the Andes conditions were formed for high precipitation and rainforest development east of the mountain chain.

The development of the Amazonian rainforest was strongly affected and controlled by changes in sea level and in climate. This is the prime topic of this paper.

\section{Changes in Sea Level and Climate}

Sea level changes for many different reasons [3] [4]. So-called global changes [4]-[8] are questioned. No signal is truly global. It is always affected by local and regional modifications [3] [4]. The South American east coast, however, offers exceptionally favorable conditions to trace and record general changes in sea level along this passive continental margin over an area from Venezuela at Lat. $10^{\circ} \mathrm{N}$ down to Tierra del Fuego at Lat. $55^{\circ} \mathrm{S}$ and further down to the Antarctic Peninsula down to Lat. $70^{\circ} \mathrm{S}$. A very simple general picture emerges consisting of 3 major sea level high-stands and 3 periods of significant low-stands in the last 30 (Figure 1) [2].

A cartoon of the corresponding paleographic situations of South America during the last 30 ma is given in Figures 2(a)-(f).

\subsection{The Antarctic Peninsula}

During the Swedarp Expedition to Antarctica in 1988/89, I studied Cenozoic changes in sea level and climate of the Antarctic Peninsula and South Shetland Islands with respect to sediment characteristics, biota changes and magnetostratigraphy [9].

In the Early Eocene, climate was temperate, forest vegetation existed and organic productivity was high (as evidenced from the gyttja content in estuarine mud, besides biota diversity). Three phases of higher sea level positions are recorded at approximately 20, 10 and $3 \mathrm{ma}$, or at more or less the same time intervals as the high sea level epochs in Patagonia [10].

\subsection{Patagonia and Parana Basin}

Our research-team has studied the sea level changes and glacial chronology in Argentina since many years by means of biostratigraphy and magnetostratigraphy [10] [11]. Prior to $24 \mathrm{ma}$, sea level was generally low and climate warm. This period is known as "Tobas con mamiferos". At around the Oligocene/Miocene boundary24 to 18 ma ago — sea level was high and widespread deposits with marine biota were laid down (Figure 2(a)). We know it as the Patagonian Formation (or "Patagoniense"). From 18 ma (or slightly after) to an unspecified time at around 12-13 ma, sea level was low (Figure 2(b)). This period is known as the Santa Cruzian Formation.

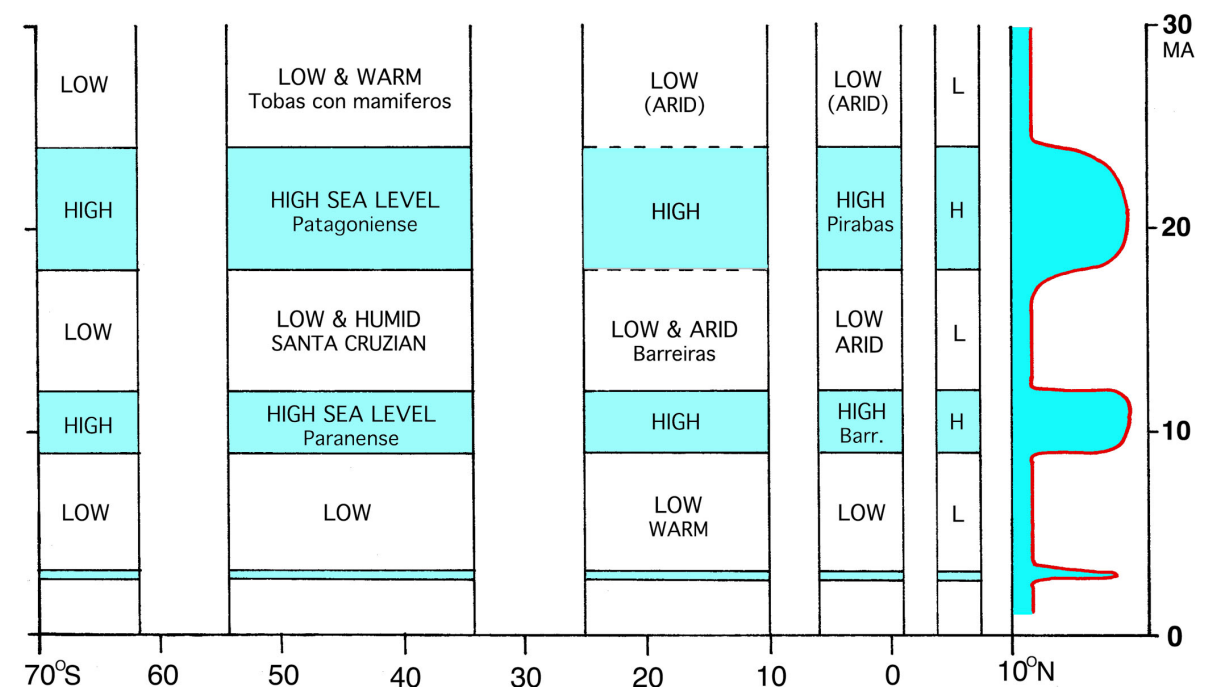

Figure 1. Sea level changes in the last $30 \mathrm{ma}$ as recorded along the passive continental margin of Eastern South America from Lat. $10^{\circ} \mathrm{N}$ to Lat. $55^{\circ} \mathrm{S}$ plus extension to the Antarctic Peninsula down to Lat. $70^{\circ} \mathrm{S}$. Three main periods of sea level high-stand are recorded (right hand column) all along the coasts; viz. 20, 10 and 3 ma. 


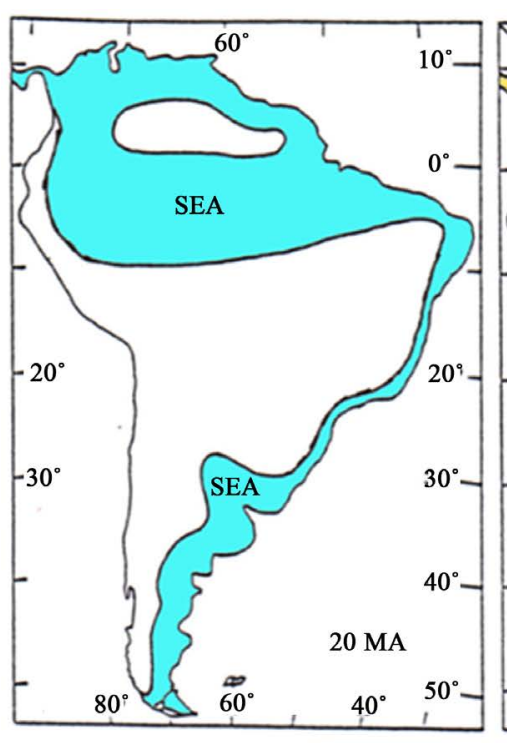

(a)

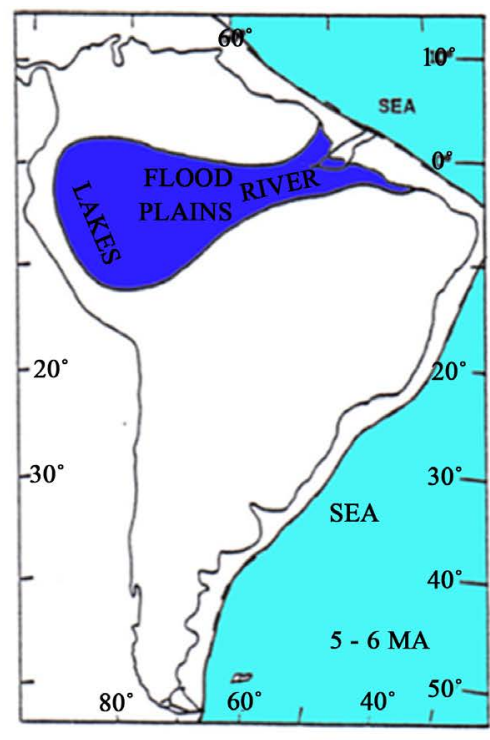

(d)

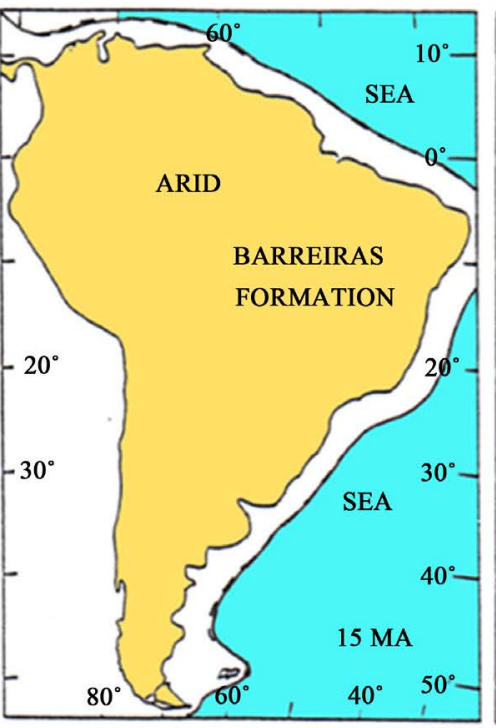

(b)

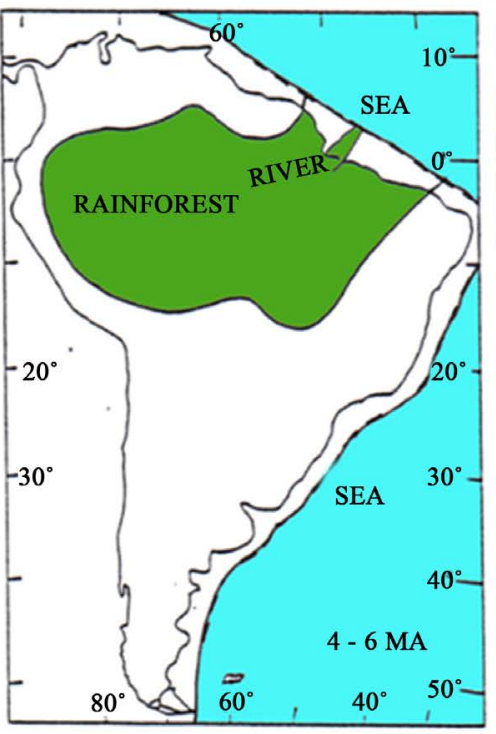

(e)

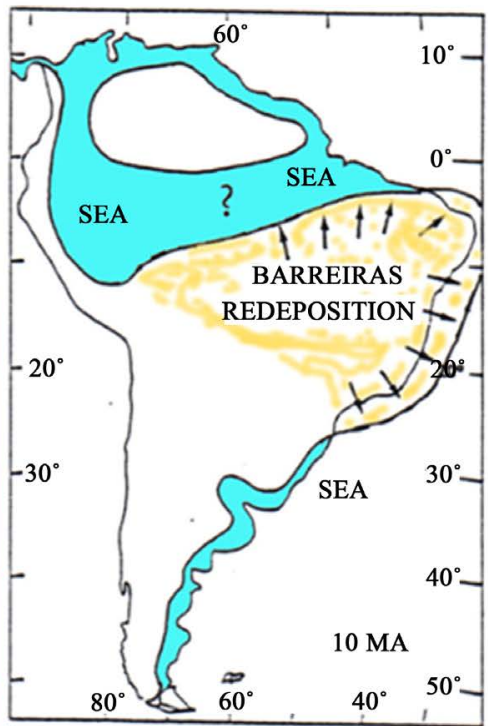

(c)

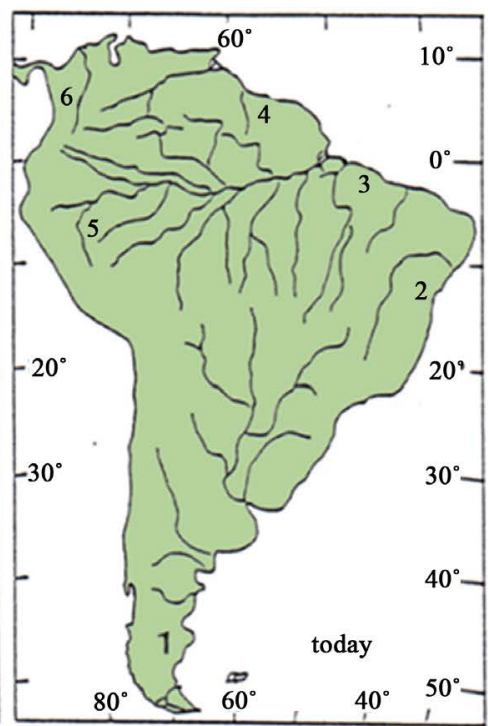

(f)

Figure 2. Paleogeographic changes in sea level and climate conditions during the last 30 ma in South America (cf. [2]). (a) the high sea level stage at 24 - $18 \mathrm{ma}$; (b) the low sea level and arid to sub-arid period at 18 - $15 \mathrm{ma}$; (c) the high sea level stage at 15 - 10 ma; (d) the Amazonian basin was characterized by flood plains, lakes and rivers at around 6 - 5 ma; (e) in the Late Miocene, at 6 - 4-ma, the situation changed drastically and the huge Amazonian rainforest ecosystem was established; (f) the present fluvial systems of South America with Patagonia (1), the Salvador area (2), the Bélem area (3), the Guiana area (4), the eastern Peru area (5) and Colombia area (6) marked.

Climate was characterized by wetness and large areas seem to have been occupied by inland lakes. Sea level experienced a second high in Mid Miocene time some 12/13 to 9.5 ma ago (Figure 2(c)). This is known as the Parana Formation (or "Paranense"). This was followed by a new low sea level. In direct association with the Kaena Reversed Event, sea level experienced a rapid but pronounced rise at around 3 ma ago [11] [12]. After that, there is no evidence of higher sea levels until the last interglacial and the Holocene [10]. The $20, \sim 10$ and $\sim 3$ ma periods of high sea level, all mark important, well-expressed sea level inundation of vast areas. The faunal differences are clear. Each of these high sea level epochs seems to include a number of minor sub-cycles. In this paper, I put emphasis on the 3 main high stands, however (Figure 1) [2]. 


\subsection{The Amazonian Basin and Brazilian Coast}

In northeastern Brazil, there is evidence of 2 or 3 high sea level periods within the last 30 ma (Figure 1 and Figure 2) as previously discussed by Mörner et al. [2] and by Rossetti et al. [13].

At around the Oligocene/Miocene boundary, sea level was at least 40-50 m higher than at present and vast areas of southeastern Amazonia were inundated by the sea as evidenced by shallow marine and estuarine deposits of the Pirabas Formation [14]-[16] (Figure 2(a)). Obviously, it is a time equivalent to the Patagonian Formation in Argentina. Hoorn et al. ([17] their Figure 1(a)) indicate a limited inundation, whilst Mörner et al. ([2] their Figure 3(b)) give an extensive inundation with a probable (or, at least, possible) cross-Amazonian sea connection (Figure 2(a)).

Then followed a period of low sea level (just as in Patagonia). This period, lasting from about 18 to 13 ma, was characterized by arid to semi-arid climatic conditions (Figure 2(b)). Kaolin weathering of the granitic bedrock and the development of a deep lateritic soil extend over a very large area along the coastal zone of Brazil, in the Amazonian basin and northwards in over the northeastern parts of South America. These deposits have become known as the Barreiras Formations [18]-[21]. The prevailing climatic conditions must (Figure 2(b)) have been very warm or rather arid [2]. This means climatic conditions that cannot be combined with rainforest occurrence, at least not along the eastern parts of the main basin.

Subsequently and in association with a rising sea level, the Barreiras Formation became re-deposited and intermixed with marine material. A second high sea level occurred in the Mid Miocene some 12 to 9 ma ago (Figure 2(c)). It is known as the Middle and Upper Barreiras Formation and is represented by tidal deposits covering a wide area [12] [22]-[24]. In the Salvador area, the Barreiras Formation is graded to a level far outside the present coast ([2], their Figure 3(D)) suggesting that re-deposition and accumulation of the weathering products took place at a rising sea level with the shoreline still located well outside the present coast. This would explain why only terrestrial environmental conditions are recorded [25]. This high sea level positions is a correlative to the Pebas, Solimões and Unumaco Formations in the west and northwest [1] [26]-[28]. It is a time equivalent to the Parana Formation in Argentina. During this high sea level epoch, too much of the Amazonian basin was flooded by the sea for the existence of any large-scale cover of rainforest. Hoorn et al. ([17] their Figure 1(b)) give a major inundation in the west and a small coastal inundation in the east. Mörner et al. ([2] their Figure 3(d)) record an extensive inundation with a probable cross-Amazonian connection (Figure 2(c)).

Sea level fell to a second low-stand within the Tortonian some 9 - 6 ma ago. Mann de Toledo reports (in [2]) that the biota indicates "a savanna-grassland setting intermingled with large bodies of water separated by gallery forests"; i.e. something quite different form a dense rainforest vegetation.

\subsection{The Coast in the Northeast}

From the Suriname region, Wong [29] reported a very similar sequence of high and low sea level as those recorded in Argentina and Brazil [2]. Within the Miocene and Pliocene of Surinam, he recorded three periods of high sea level and coastal inundation (Figure 1 and Figure 2), viz. 1) at the Oligocene/Miocene boundary, 2) in the Mid Miocene, and 3) in the Pliocene.

\subsection{Synthesis of Sea Level Changes in the Last $30 \mathrm{ma}$}

Figure 1 summarizes the high and low sea level stands along the coasts from the Antarctic Peninsula in the south at Lat $70^{\circ} \mathrm{S}$ to the Caribbean coasts in the north at Lat. $10^{\circ} \mathrm{N}$. Three periods of high sea level are easily identified all along the section; viz. at $\sim 20, \sim 10$ and $\sim 3$ ma. Figure 2 gives the paleogeographic reconstructions.

\section{Origin of the Amazonian Rainforest}

The origin of the Amazonian rainforest was driven by three main factors (Figure 3); viz. 1) the uplift of the Andes to the west, 2) the prevailing climatic conditions within the region, and 3) the presence or absence of ground inundated by the sea (i.e. the sea level changes). All three factors, as discussed below, suggest an origin in the Late Miocene [2].

The formation of the Andean Cordillera began some 40 ma ago [30]. The elevation remained in the order of $1000-1500 \mathrm{~m}$ up to $10-14 \mathrm{ma}$ [30] [31], which seems too low to have any significant effect on vegetation and precipitation of the eastern slopes and in the Amazonian basin. In the last 9 - 10 ma, however, uplift accelerated 


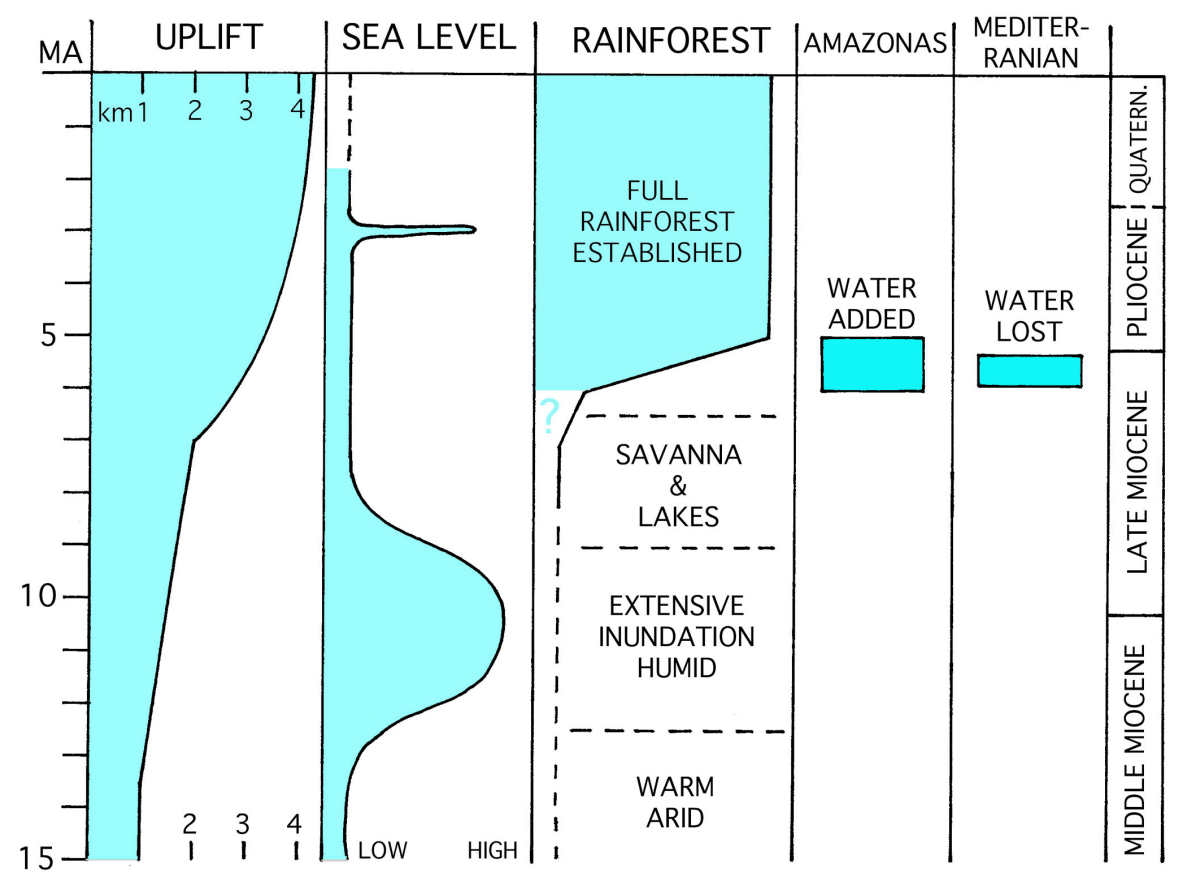

Figure 3. Uplift, sea level changes and rainforest establishment (with preceding environmental changes within the Amazonian basin) during the last 15 ma. "Water added" into the Amazonian system and "water lost” from the Mediterranean are coincidental, suggesting a causal connection.

[30]-[33] successively bringing the Andes up to its present elevation of 4000-4500 m. According to Lamb and Davis [30], it had, at $7 \mathrm{ma}$ ago, still only an elevation of about $2000 \mathrm{~m}$. This may be taken to suggest that conditions were, at $7 \mathrm{ma}$ ago, still not available for the creation of an extensive rainforest vegetation. Along the eastern foot of the Andes in being, rainforest communities were established earlier as recorded by pollen data [1] [27] [34]. According to Gregory-Wodzicki [33] 60\% of the uplift of the Eastern Cordillera of the Colombian Andes took place in the last 4 ma.

During the high sea level around 20 and 10 ma, too large areas were inundated ([2] their Figure 1(d)) for the occurrence of an extensive rainforest cover (Figure 2(a) \& Figure 2(c)). Therefore, it should have commenced in the regressional phase after 9.5 ma.

The climatic conditions were too warm and arid for rainforest establishment (more than along the mountainfoot in the west) during the regressive phases around 25 and 15 ma (Figure 2(b)).

The change from aridity to rainforest establishment is likely to have passed through a transitional phase of large lakes. In the western Amazonian region (Acre), large lakes (with huge crocodiles of 14 - $15 \mathrm{~m}$ length) and savanna-vegetation are recorded from the Late Miocene [2].

The first fluvial plains in central Amazonas are of Pliocene age [35]. The establishment of a trans-continental drainage via overfilling of the Andean foreland basins occurred in the Late Miocene as indicated by the distribution of neotropical fishes ([17] [36] Figure 1(c)). This implies conditions in favor of a rainforest establishment in the Late Miocene or some 6 - 5 ma ago as proposed by Mörner et al. [2].

Modern genetics support this conclusion. In a study of the mutation frequency of both birds and fishes, Bates [37] [38] arrives at the conclusion that the recorded frequencies suggest a time of evolution in the order of some 2 - $6 \mathrm{ma}$.

In conclusions, available data are all indicative of an age of the establishment of the Amazonian rainforest (of present-day dimensions) not prior to 6 - 7 ma ago (Figure 3). At 7 ma, some $50 \%$ of the uplift of the Andes still remained. The sea level regression after 9.5 ma provided conditions favorable for an evolution towards rainforest establishment. A transitional period of savanna vegetation and occurrence of large lakes seems to have existed. In the Late Miocene a trans-continental drainage was established providing final circumstances for a large rainforest establishment. An age for the commencement of an extensive rainforest cover over the Amazonian basin, therefore, seems to have been in the order of 6 - 5 ma ago (Figure 3). 


\section{Impact on the Global Hydrological Cycle}

The global hydrological cycle implies a balanced flux between different variables and a temporary or permanent storage of large quantities of water elsewhere [39]-[41]. Sea level changes usually represent the transfer of water between the oceans and continental ice caps. The establishment of the Amazonian rainforest (sensu hodierno) implied the storage of very large quantities of water in the fluvio-lacustrine system, in the soil and sub-surface, in the rainforest biota, and in the water recycled within the rainforest system itself.

\section{Global Water Vapor Changes}

Enormous quantities of water are trapped the Amazonian rainforest system. This water is partly stored within the system and partly re-circulating within the system itself. This implied an enormous withdrawn of water from the global hydrological circulation system.

The means of getting this water quantity into the Amazonian system is by precipitation (Figure 4). Precipitation implies withdrawal of air-born water vapor. This calls for an increased re-charging of water vapor by increased evaporation at another part of the globe. Increased evaporation that is consumed by increased precipitation becoming trapped in the Amazonian rainforest system must imply a decrease in oceanic water volume (with eustatic lowering of sea level) and/or drying up of lakes and inland seas.

In this paper (also [2]), it is claimed that the Amazonian rainforest came into existence some 6 - 5 Ma ago (or, at least, after the $10 \mathrm{Ma}$ high sea level position). This is at about the same time as the well-known Messinian salinity crisis in the Mediterranean when regional evaporation suddenly increased dramatically leading to the drying-up of the Mediterranean [42]-[47]. The origin of the Messinian salinity crisis has previously remained problematic. A new, quite logical, scenario seems now to appear; viz. that the withdrawal of water vapour into the Amazonian rainforest system some 6 to 5 ma ago initiated an increased evaporation from the Mediterranean (and, maybe, other areas, too) leading to the Messinian salinity crisis (Figure 4).

The Messinian salinity crisis is dated between 5.96 and 5.33 ma [45]. The Mediterranean level was drastically lowered and extensive evaporates were formed. The volume of water gone was about $3.7 \times 10^{6} \mathrm{~km}^{3}$ (a volume capable of lowering global sea level by about $10 \mathrm{~m}$ ).

This scenario was pinpointed in even more details by Clauzon et al. [46], who were able to identify an initial minor sea level regression in the period 5.97 - 5.60 ma, a major regression with an almost complete desiccation of the Mediterranean Sea in the period 5.60 - $5.46 \mathrm{ma}$, and a rapid marine transgression commencing 5.46 ma.

According to Popescu et al. [47], the Messinian/Zanclean boundary can be fixed at 5.332 ma (i.e. just as proposed by [45]).

\section{Conclusions}

The paper is summarized in the following five main conclusions:

1) The Andes were rapidly uplifted in the last 7 ma (Figure 3).

2) Sea level experienced three high-stands in the last $30 \mathrm{ma}$; at $\sim 20, \sim 10$ and $\sim 3 \mathrm{ma}$. These high-stands are recorded all along the coasts from $70^{\circ} \mathrm{S}$ to $10^{\circ} \mathrm{N}$ (Figure 1 and Figure 2).

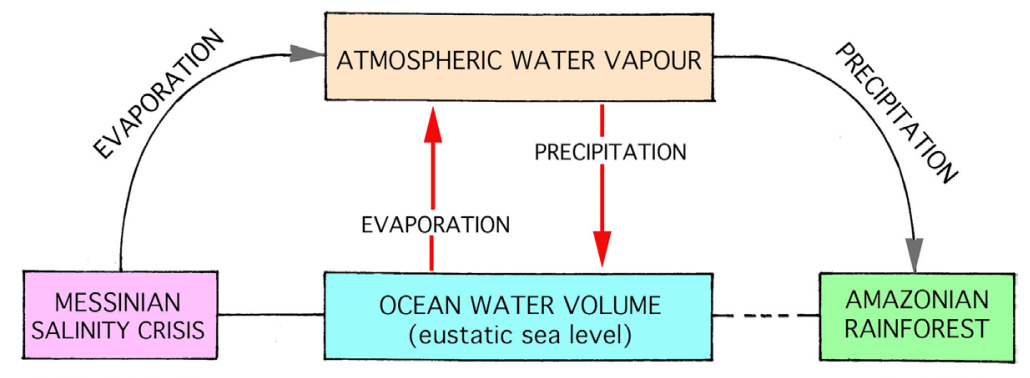

5.96-5.33 MA

$\sim 6-5 \mathrm{MA}$

Figure 4. Enormous quantities of water were lost into the Amazonian rainforest system captured precipitation at the same time as enormous quantities of water were lost from the Mediterranean by evaporation. The loss in precipitation seems to have generated a compensational gain in evaporation. 
3) During the low-stands $\sim 25$ and $\sim 15$ ma, the climatic conditions in the region of the Amazonian Basin were arid to semi-arid (Figures 1-3).

4) The establishment of a rainforest (sensu hodierno) within the Amazonian Basin seems to have occurred some 6 - 5 ma ago (Figure 2(e) and Figure 3).

5) The trapping of enormous quantities of water within the Amazonian rainforest and fluvial system seems to have been balanced by increased evaporation elsewhere (Figure 4). The Mediterranean salinity crisis is coincidental in time and a causal linkage is proposed.

\section{Acknowledgements}

The author has undertaken active filed studies in Antarctica (1989), Argentina (1988-1992), Brazil (as consultant in physics at the University of Bahia in Salvador in 1980, and as visiting professor at Museu Paraense Emilio Goeldi in Bélem in 1997), French Guyana, Venezuela, Columbia, Peru and Chile. The author declares no conflict of interest.

\section{References}

[1] Hoorn, C. (1993) Marine Incursions and the Influence of Andean Tectonics on the Miocene Depositional History of Northwestern Amazonia: Results of a Palynological Study. Palaeogeography, Palaeoclimatology, Palaeoecology, 105, 267-309. http://dx.doi.org/10.1016/0031-0182(93)90087-y

Hu, T. and Desai, J.P. (2004) Soft-Tissue Material Properties under Large Deformation: Strain Rate Effect. Proceedings of the 26th Annual International Conference of the IEEE EMBS, San Francisco, 1-5 September 2004, 2758-2761. http://dx.doi.org/10.1109/iembs.2004.1403789

[2] Mörner, N.-A., Rossetti, D. and Mann de Toledo, P. (2001) The Amazonian Rainforest Only Some 6-5 Million Years Old. Biological and Cultural Diversity of Amazonia, Museu Paraense Emilio Goeldi, 3-18, Bélem, Pará.

[3] Mörner, N.-A. (1987) Models of Global Sea-Level Changes. In: Tooley, M.J and Shennan, I., Eds., Sea Level Changes, Blackwell, Oxford, 332-355.

[4] Mörner, N.-A. (2013) Sea Level Changes: Past Records and Future Expectations. Energy \& Environment, 24, 509-536. http://dx.doi.org/10.1260/0958-305X.24.3-4.509

[5] Vail, P.R., Michtum, K.G., Thomson III, S., Todd, R.G., Sangree, J.B., Widmeir, J.M., Bubb, J.N. and Hatlelid, W.G. (1977) Seismic Stratigraphy and Global Changes in Sea Level. AAPG Memoir, 26, 49-212.

[6] Haq, B.U., Hardenbol, J. and Vail, P.R. (1987) Chronology of Fluctuating Sea Levels Since the Triassic (250 Myr to Present). Science, 235, 1156-1167. http://dx.doi.org/10.1126/science.235.4793.1156

[7] Haq, B.U. (2014) Cretaceous Eustasy Revisited. Global Planetary Change, 113, 44-58. http://dx.doi.org/10.1016/j.gloplacha.2013.12.007

[8] Cloetingh, S. and Haq, B.U. (2015) Inherited landscapes and Sea Level Change. Science, 347, 393-404. http://dx.doi.org/10.1126/science.1258375

[9] Mörner, N.-A., Mujica, A. and da Rocha, P. (1990) Cenozoic Magnetostratigraphy, Sedimentary Dynamics, Paleoclimatology, Sea-Level Changes and Related Problems. Swedish Antarctic Research Programme 1988/89. A Cruise Report, Swedish Polar Research Secretariat, Stockholm, 98-102.

[10] Mörner, N.-A. and Mujica, A. (1989) General Cenozoic Sea-Level Changes and Paleo-Environmental Changes in Antarctica and Argentina. Abstracts, 28th IGC, Washington DC, 2, 463.

[11] Mörner, N.-A. (1991) The Patagonian Glaciations and the Onset of General Quaternary-Type Glaciations on the Globe. Boletim IG-USP. Publicação Especial, 8, 109-115.

[12] Bidegain, J.C. (1991) Sedimentary Development, Magnetostratigraphy and Sequence of Events of the Late Cenozoic in Entre Rios and Surrounding Areas in Argentina, Ph.D.-Thesis, Paleogeophysics \& Geodynamics, Stockholm University, Stockholm.

[13] Rossetti, D.F., Bezerra, F.H.R. and Dominguez, J.M.L. (2013) Late Oligocene-Miocene Transgressions along Equatorial and Eastern Margins of Brazil. Earth-Science Reviews, 123, 87-112. http://dx.doi.org/10.1016/j.earscirev.2013.04.005

[14] Góes, A.M., Rossetti, D.F., Nogueira, A.C.R. and Toledo, P.M. (1990) Modelo deposicional preliminar da Formacao Pirabas no nordest do estado do Pará. Boletim Museu Paraense Emilio Goeldi, Serie Ciencia Terra, 2, 3-15.

[15] Rossetti, D.F. (2000) Influence of Low Amplitude/High Frequency Relative Sea-Level Changes in a Wave-Dominated Estuary (Miocene), São Luís Basin, Northern Brazil. Sedimentary Geology, 133, 295-324.

http://dx.doi.org/10.1016/S0037-0738(00)00046-4 
[16] Rossetti, D.F. (2001) Sedimentary Evolution of Late Cenozoic in the Northeast of Pará State, Brazil: First Evidence of Sea Level Fluctuations. Journal of South American Earth Sciences, 14, 77-89. http://dx.doi.org/10.1016/S0895-9811(01)00008-6

[17] Hoorn, C., Guerrero, J., Sarmiento, G.A. and Lorente, M.A. (1995) Andean Tectonics as a Cause for Changing Drainage Patterns in Miocene Northern South America. The Geological Society of America, 23, 237-240. http://dx.doi.org/10.1130/0091-7613(1995)023<0237:ATAACF >2.3.CO;2

[18] Oliviera, A.J. and Leonardos, O.H. (1943) Geologia do Brasil. 2. Ministerio Agricultura, Rio de Janeiro, 813 p.

[19] Oliviera, A.J. and Ramos, J.R.A. (1956) Geologia das quadriculas de Recife et Pontas de Pedra. Boletim Diversidade Geologia Mineralogia, DNP, 151, 1-60.

[20] Bigarella, J.J. and Andrade, G.O. (1964) Consideracões sobre a estratigrafia dos sedimentos conozoicos em Pernambuco (Grupo Barreiras). Arqueologia Instituto, 2, 2-14.

[21] Rossetti, D.F. and Góes, A.M. (2009) Marine Influence in the Barreiras Formation, State of Alagoas, Northeastern Brazil. Anais da Academia Brasileira de Ciências, 81, 741-755. http://dx.doi.org/10.1590/S0001-37652009000400012

[22] Arai, M., Uesugui, N., Rossetti, D.N. and Góes, A.M. (1988) Consideracoes sobre a idade do Grupo Barreiras no nordeste de estado do Pará. Congresso Brasiliero Geologico, 35, 738-752.

[23] Rossetti, D.F., Truckenbrodt, W. and Góes, A.M. (1989) Estudo paleambiental e estratigtáfico dos sedimentos Barreiras e pós-Barreiras na redião Bragantina, nordeste do Pará. Boletim Museu Paraense Emilio Goeldi, Serie Ciencia Terra, 1, 25-74.

[24] Rossetti, D.F., Truckenbrodt, W. and Góes, A.M. (1990) A Influencia marinha nos sedimentos Barreiras. Boletim Museu Paraense Emilio Goeldi, Serie Ciencia Terra, 2, 17-29.

[25] Martin, L., Suguio, K., Flexor, J.-M., Dominquez, J.M.L. and Bittencourt, A.C.S.P. (1996) Quaternary Sea-Level History and Variation in Dynamics along the Central Brazilian Coast: Consequences on Coastal Plain Construction. Anais da Academia Brasileira de Ciências, 68, 303-354.

[26] Nuttall, C.P. (1990) A Review of Tertiary Non-Marine Molluscan Faunas of the Pebasian and Other Inland Basins of Northwestern South America. Bulletin British Museum of Natural History (Geology), London, 45, 65-371.

[27] Hoorn, C. (1994) An Environmental Reconstruction of the Palaeo-Amazon River System (Liddle-Late Miocene, NW Amazonia). Palaeogeography, Palaeoclimatology, Palaeoecology, 112, 187-238. http://dx.doi.org/10.1016/0031-0182(94)90074-4

[28] Räsänen, M.E, Salo, J.S., Jungnert, H. and Romero-Pittman, L. (1990) Evolution of the Western Amazon Lowland Relief: Impact of Andean Foreland Dynamics. Terra Nova, 2, 320-332. http://dx.doi.org/10.1111/j.1365-3121.1990.tb00084.x

[29] Wong, T.E. (1992) Quateranry Stratigraphy of Suriname. In: Prost, M.-T., Ed., Èvolution des littoreaux de Guyane et de la zone Caraïbe Méridionale pendant le Quaternaire, ORSTOM, Paris, 559-578.

[30] Lamb, S. and Davis, P. (2003) Cenozoic Climate Change as a Possible Cause for the Rise of the Andes. Nature, 425, 792-797. http://dx.doi.org/10.1038/nature02049

[31] Hartley, A.J. (2003) Andean Uplift and Climate Change. Journal of the Geological Society London, 160, 7-10. http://dx.doi.org/10.1144/0016-764902-083

[32] Gubbels, T.L., Isacks, B.L. and Farrar, E. (1993) High-Level Surfaces, Plateau Uplift, and Foreland Development, Bolivian Central Andes. Geology, 21, 695-698. http://dx.doi.org/10.1130/0091-7613(1993)021<0695:HLSPUA>2.3.CO;2

[33] Gregory-Wodzicki, K.M. (2000) Uplift history of the Central and Northern Andes: A Review. Geological Society of America Bulletin, 112, 1091-1105. http://dx.doi.org/10.1130/0016-7606(2000)112<1091:UHOTCA >2.0.CO;2

[34] Hoorn, C. (1994) Fluvial Palaeoenvironments in the Intracratonic Amazonian Basin (Early Miocene to Early Middle Miocene, Comombia). Palaeogeography, Palaeoclimatology, Palaeoecology, 109, 1-55. http://dx.doi.org/10.1016/0031-0182(94)90117-1

[35] Irion, G., Müller, J., de Mello J.N. and Junk, W.J. (1995) Quaternary Geology of the Amazonian Lowland. Geo-Marine Letters, 15, 172-178. http://dx.doi.org/10.1007/BF01204460

[36] Lundberg, J.G., Marshall, L.G., Guerrero, J. and Malabarba, M.C.S.L. (1998) The Stage of Neotropical Fish Diversification: A History of Tropical South American Rivers. Philogeny and Classification of Neotropical Fishes, Porto Alegre, Edipucrs, 603 p.

[37] Bates, J. (1996) Molecular Markers as Tools for Reconstructing the History of Amazonia. 130 Years' anniversary Symposium of Museu E. Goeldi on Diversidade Biologica e Cultura da Amazonia em un Mundo em Transformacao. Belém, Brazil.

[38] Bates, J. (2001) Avian Diversification in Amazonia: Evidence for Historical Complexity and a Vicariance Model for a 
Basic Diversification Pattern. Biological and Cultural Diversity of Amazonia, Museu Paraense Emilio Goeldi, Bélem, Pará, 119-138.

[39] Gregory, K.J. (1983) Background to Paleohydrology. Wiley \& Sons, Hoboken, 510 p.

[40] Newson, M. (1994) Hydrology and the River Environment. Clovedon Press, Oxford, 221 p.

[41] Gregory, K.J. and Benito, G. (2003.) Palaeohydrology. Understanding Global Change. Wiley \& Sons, Hoboken, 396 p.

[42] Hsü, K.J., Cita, M.B. and Ryan, W.B.F. (1973) Origin of the Mediterranean Evaporises. Initial Reports, DSDP, 13, 12031231.

[43] Cita, M.B. (1976) Biodynamic Effect of the Messinian Salinity Crisis on the Evolution of Planctonic Foraminifera in the Mediterranean. Palaeogeography, Palaeoclimatology, Palaeoecology, 20, 23-42. http://dx.doi.org/10.1016/0031-0182(76)90023-7

[44] Haq, B.U. (1984) Paleocenography: Asynoptic Overview of 200 Million Years of Ocean History. In: Haq, B.U. and Milliman, J.D., Eds., Marine Geology and Oceanography of Arabian Sea and Coastal Pakistan, Van Nostrand Reinhold Co., New York, 201-231.

[45] Krijgsman, W., Hilgen, F.J., Raffi, I., Sierro, F. and Wilson, D.S. (1999) Chronology, Crisis and Progression of the Messinian Salinity Crisis. Nature, 400, 652-655. http://dx.doi.org/10.1038/23231

[46] Claauzon, G., Sic, J.-P., Do Couto, D. and 17 Others (2015) New Insights on the Sorbas Basin (SE Spain): The Onshore Reference of the Messinian Salinity Crisis. Marine and Petroleum Geology, 66, 71-100. http://dx.doi.org/10.1016/j.marpetgeo.2015.02.016

[47] Popescu, S.-M., Dalibard, M., Suc, J.-P. and 10 Others [2015) Lago Mare Episodes around the Messinian-Zanclean Boundary in the Deep Southwestern Mediterranean. Marine and Petroleum Geology, 66, 55-70. http://dx.doi.org/10.1016/j.marpetgeo.2015.04.002 